\title{
PENGARUH VISUAL MERCHANDISING, PERSONAL SELLING DAN PRODUCT QUALITY TERHADAP PURCHASE INTENTION PADA PRODUK KOSMETIK LT PRO DI SURABAYA
}

\author{
Melisa Gunawan ${ }^{1}$ dan Edwin Japarianto ${ }^{1 *}$ \\ Jurusan Manajemen Pemasaran, Universitas Kristen Petra \\ E-mail: melisa.g_19@yahoo.com; edwinj@petra.ac.id \\ * Korespondensi
}

\begin{abstract}
Abstrak: Penggunaan kosmetik untuk wanita telah menjadi umum di antara orang-orang. LT Pro menjadi jawaban kebutuhan perempuan ini tersebar di saluran modern menjadi mudah ditemukan pelanggan. LT Pro juga menyediakan pilihan produk kosmetik dengan kualitas yang baik dan layanan yang dapat menjawab kebutuhan konsumen. Penelitian ini menyebarkan kuesioner kepada 100 responden wanita di konter LT Pro dengan menggunakan teknik analisis kuantitatif dengan metode Cluster, Multi Dimensi Scaling (MDS) dan Regresi Linear. Hasil penelitian ini menunjukkan adanya tiga kelompok utama konsumen LT Pro. Variabel visual merchandising, penjualan personal dan kualitas produk dibagi dalam dua dimensi, yaitu dimensi estetika dan informasi. Hubungan variabel visual merchandising memiliki tidak signifikan terhadap niat beli variabel, sedangkan personal selling dan kualitas produk memiliki hubungan yang signifik
\end{abstract}

Kata kunci: Visual merchandising, penjualan personal, kualitas produk, niat beli

\begin{abstract}
The use of cosmetics for women have become common among the people. LT Pro answers the needs of these women are scattered in modern channel to be easily found customers. LT Pro also provides the option of cosmetic products with good quality and service that can answer the needs of consumers. This research distributing questionnaires to 100 respondents woman at the counter LT Pro by using quantitative analysis techniques with methods Cluster, Multi Dimensional Scaling (MDS) and Multiple Linear Regression. The results of this study indicate the existence of three main groups of consumers LT Pro. Variable visual merchandising, personal selling and product quality is divided in two dimensions, ie the dimensions of aesthetics and information. And visual variables merchandisingmemiliki relationship is not significant to the variable purchase intention, while personal selling and product quality has a significant relationship.
\end{abstract}

Keywords: Visual merchandising, personal selling, product quality, purchase intention

\section{PENDAHULUAN}

Kaum wanita identik dengan keindahan, sehingga menjadi hal yang wajar untuk seorang wanita ingin tampil cantik dan menarik serta menjadi perhatian bagi lingkungan sekitarnya. Menurut penelitian sebelumnya (Chiang, 2010) didapatkan data bahwa sebanyak $58.7 \%$ kaum wanita yang berumur $19-25$ tahun sudah mulai menggunakan kosmetik. Penjualan kosmetik pada tahun 2015 yang sekarang berada di angka Rp 13,943 triliun dari sebelumnya yang hanya sebanyak Rp 12,874 triliunmengindikasikan adanya peningkatan dalam konsumsi kosmetik di masyarakat (cci-indonesia.com, 2016).

LT Pro mulai diperkenalkan sebagai produk make up dekoratif pada tahun 2009 untuk membuktikan kepada kaum wanita bahwa make-up sempurna bisa didapatkan siapa saja melalui produk yang tepat (lt-pro.com, 2016). Produk LT Pro yang tersebar hampir di seluruh department store memiliki visual merchandising untuk ditunjukkan kepada konsumen. LT Pro menggunakan window display untuk menarik perhatian konsumen. LT Pro memiliki penekanan terhadap komposisi dari window display yang ditunjukkan kepada konsumen dimana dua puluh persen dari window display merupakan fast moving product, dua puluh persen lainnya adalah new product dan sisanya, yaitu sebanyak enam puluh persen, adalah slow moving product. Selain itu, LT Pro memiliki personal selling di setiap outlet modern channel yang dikenal dengan istilah beauty advisor (BA). Beauty advisor diharapkan dapat membantu memberikan solusi kepada konsumen mengenai kebutuhan konsumen tersebut. Product quality dari LT Pro sendiri sudah tidak perlu diragukan lagi, dengan menggunakan user-based approach, produk LT Pro dinilai dapat memenuhi kebutuhan konsumen. Berdasarkan pada latar belakang di atas, maka dari itu peneliti ingin meneliti pengaruh visual merchandising, personal selling dan product quality terhadap purchase intention pada produk kosmetik LT Pro di modern channel kota Surabaya.

\section{TINJAUAN PUSTAKA}

\section{Visual Merchandising}

Visual merchandising menjadi "bahasa sebuah toko" dimana penjual berkomunikasi dengan konsumennya 
melalui gambar atau presentasi produk (Ebster, 2011). Seiring dengan perkembangannya, visual merchandising bukan hanya digunakan untuk memperindah outlet, namun visual merchandising dipercaya dapat meningkatkan penjualan (Bell \& Ternus, 2012).

\section{Personal Selling}

Personal selling adalah proses komunikasi dimana kebutuhan konsumen diusahakan terpenuhi melalui pertukaran informasi secara langsung (Levy, Weitz, \& Grewal, 2014). Salesperson diharapkan dapat menanggapi segala kebutuhan konsumen baik sebelum, selama dan sesudah penjualan.(Ingram, LaForge, Avila, Schwepker Jr., \& Williams, 2004). Personal selling menjadi penting karena persepsi konsumen mengenai kinerja salesperson akan mempengaruhi kepuasan mereka terhadap outlet dan pengalaman belanja mereka. (Sullivan \& Adcock, 2002).

\section{Product Quality}

Product quality menjadi salah satu perhatian konsumen karena konsumen dewasa ini menginginkan produk dengan kualitas tinggi yang dapat menghemat waktu dan energy (Shaharudin, Mansor, Hassan, Omar, \& Harun, 2011). Product quality menjadi proses peningkatan yang berkelanjutan untuk terus memperbaiki performa produk dan pada akhirnya memenuhi kebutuhan konsumen (Mirabi, Akbariyeh, \& Tahmasebifard, 2015).

\section{Purchase Intention}

Menurut Kotler \& Armstrong (2008) purchase intention adalah sesuatu yang timbul di dalam konsumen setelah menerima rangsangan dari produk yang dilihatnya. Schiffman \& Kanuk (2000) menyatakan bahwa purchase intention adalah sebuah perilaku transaksi konsumen yang cenderung muncul setelah mengevaluasi produk, dan reaksi konsumen yang muncul setelah proses evaluasi tersebut akan mengukur kemungkinan konsumen akan melakukan pembelian atau tidak. Tee, Gharleghi, Chan, Samadi, \& Balahmar (2015) menyatakan bahwa purchase intention adalah keadaan saat konsumen hendak membeli sebuah barang atau jasa lagi dan lagi dikarenakan barang atau jasa tersebut dapat memenuhi kepuasan konsumen.

\section{Kerangka Konseptual}

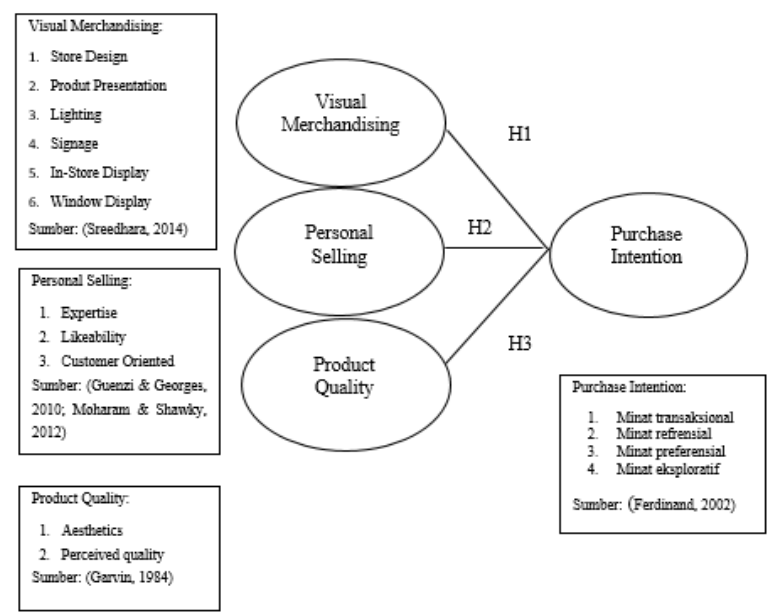

Gambar 1. Kerangka Konseptual

\section{Hipotesis}

$\mathrm{H}_{1}$ : Visual Merchandising berpengaruh terhadap Purchase Intenton

$\mathrm{H}_{2}$ : Personal Selling berpengaruh terhadap Purchase Intention

$\mathrm{H}_{3}$ : Product Quality berpengaruh terhadap Purchase Intention

\section{METODOLOGI PENELITIAN}

\section{Jenis Penelitian}

Pendekatan yang digunakan dalam penelitian ini adalah pendekatan kuantitatif, dimana metode yang digunakan adalah metode survey kuesioner terstruktur yang diberikan kepada sampel dari sebuah populasi dan didesain untuk memperoleh informasi yang spesifik dari responden (Malhotra, 2004).

\section{Populasi dan Sampel}

Populasi adalah gabungan seluruh elemen yang memiliki serangkaian karakteristik serupa, yang mencakup semesta untuk kepentingan masalah riset pemasaran (Malhotra, 2004). Populasi dalam penelitian ini adalah pengguna yang pernah menggunakan produk makeup LT Pro.

Sampel adalah bagian dari jumlah dan karakteristik yang dimiliki oleh populasi tersebut (Sugiyono, 2009). Teknik pengambilan sampel pada penelitian ini menggunakan teknik non-probability sampling, dimana semua populasi tidak memiliki peluang yang sama untuk menjadi responden dan pengambilan sampel didasarkan pada pertimbangan peneliti (Simamora, 2002). 
Penelitian ini menggunakan teknik convenience sampling dimana pengambilan sampel dipilih secara spontan, yaitu siapa saja yang saat pembagian kuesioner berada di counter LT Pro.

\section{Definisi Operasional Variabel (DOV)}

1. Variabel independen dalam penelitian ini adalah:

- Visual Merchandising (X1)

Terdapat enam dimensi di dalam Visual Merchandising, yaitu store design/layout, product presentation, lighting, signage, in-store display dan window display.

- Personal Selling (X2)

Terdapat tiga dimensi di dalam Personal Selling, yaitu expertise, likeability dan customeroriented.

- Product Quality (X3)

Terdapat dua dimensi di dalam Product Quality, yaitu aesthetics dan perceived quality.

2. Variabel dependen dalam penelitian ini adalah:

- Purchase Intention

Terdapat empat dimensi di dalam Purchase Intention, yaitu minat transaksional, minat referensial, minat preferensial dan minat eksploratif.

\section{Teknik Analisa Data}

1. Uji Validitas

Uji validitas dilakukan untuk melihat apakah pertanyaan di dalam kuisioner sudah valid atau belum. Hal ini dimaksudkan agar pertanyaan di dalam kuisioner dapat mengukur apa yang akan diteliti oleh peneliti (Ghozali, 2013).

2. Uji Reliabilitas

Uji reliabilitas digunakan untuk melihat instrumen penelitian yang digunakan bersifat konsisten atau tidak, dengan bersifat konsisten maka hasil penelitian akan selalu bersifat sama meskipun disebarkan kepada sampel yang berbeda dan di waktu yang berbeda pula.

3. Regresi Linier Berganda

Menurut (Sugiyono, 2010) teknik regresi linier berganda adalah analisis yang digunakan untuk meramalkan bagaimana keadaan (naik turunnya) variabel dependen (kriterium), bila dua atau lebih variabel independen sebagai faktor prediktor dimanipulasi (dinaik-turunkannya nilai).

- Uji Asumsi Klasik

Pengujian asumsi klasik yang akan digunakan di dalam penelitian ini terdiri dari uji normalitas yang digunakan untuk menguji apakah model regresi mempunyai distribusi yang normal atau tidak, dan uji multikolinieritas digunakan untuk menguji adanya korelasi atau hubungan antarvariabel bebas (variabel independen) di dalam model regresi.

- Analisa Korelasi

Analisa korelasi digunakan untuk melihat kuatnya hubungan antara suatu variabel dengan variabel lainnya.Sehingga analisa korelasi tidak digunakan untuk mengetahui adanya hubungan sebab-akibat maupun hubungan pengaruh.

- Analisa Regresi dan Determinasi

Nilai $\left(R^{2}\right)$ yang kecil berarti kemampuan variabel independen dalam menjelaskan variasi variabel dependen amat terbatas.Nilai yang mendekati satu berarti variabel independen memberikan hampir semua informasi yang dibutuhkan untuk memprediksi variasi variabel dependen.

- T-test

T-test digunakan untuk mendapatkan nilai $t$ statistics yang diperlukan apabila peneliti ingin melakukan uji hipotesis, sehingga peneliti dapat mengatakan seberapa besar pengaruh variabel indepeden terhadap variabel dependen.

- Uji F

Uji F merupakan pengujian hubungan regresi secara simultan yang bertujuan untuk mengetahui apakah seluruh variabel independen bersama-sama mempunyai pengaruh yang signifikan terhadap variabel dependen.

4. Multi Dimensional Scalling (MDS)

MDS biasanya digunakan untuk mengidentifikasi jumlah dan sifat dimensi yang digunakan konsumen untuk mempersepsi merek-merek yang berada di pasaran, mengetahui posisi merek pada dimensi tersebut, dan posisi merek ideal yang seharusnya dimiliki oleh konsumen pada dimensidimensi tersebut.

5. Analisa Cluster

Analisa cluster atau analisa kelompok digunakan untuk mengelompokkan objek atau kasus dan terkadang variabel menjadi kelompok-kelompok yang relatif bersifat homogen.

6. Cross-tabulation

Cross tabulation atau tabulasi silang adalah tabel yang mencerminkan distribusi gabungan dua atau lebih variabel.

7. Statistik Deskriptif

Penggambaran karakteristik responden serta jawaban-jawaban responden sehingga dapat digunakan sebagai kesimpulan. 


\section{ANALISA DAN PEMBAHASAN}

\section{Profil Responden}

Responden pada penelitian ini adalah wanita dengan mayoritas berusia 21-30 tahun, memiliki profesi sebagai karyawan, dengan pengeluaran antara Rp 3.000.000,00 - Rp 5.000.000,00 dan pengeluaran yang rela dikeluarkan untuk membeli kosmetik sebesar Rp 300.000,00 - Rp 500.000,00.

\section{Analisa Cross-Tabulation}

Proses cross-tabulation menunjukkan hasil dimana responden lebih banyak yang berada di kelompok usia 21-30 tahun namun jawaban responden tersebar secara merata sehingga di setiap kelompok usia terdapat jawaban tidak setuju hingga sangat setuju. Sehingga LT Pro dapat dipilih oleh seluruh kelompok usia namun usia 21-30 menjadi kelompok usia terbanyak yang memilih LT Pro bahkan merupakan 'penggemar' dari LT Pro berbeda halnya dengan kelompok usia 17-20 tahun yang dapat memilih LT Pro namun sedikit yang menjadi 'penggemar'. Hal ini dapat terjadi dikarenakan LT Pro sendiri ditargetkan untuk kaum muda yang beranjak dewasa. Responden dengan pekerjaan sebagai karyawan mendominasi jawaban di dalam analisa tabulasi silang ini. Namun responden dengan pekerjaan sebagai pegawai negeri adalah 'penggemar' dari LT Pro. Responden dengan jumlah pengeluaran yang berbeda-beda memiliki jawaban yang hampir terdistribusi secara merata sehingga setiap kelompok responden memiliki jawaban tidak setuju hingga sangat setuju. Terakhir responden dengan pengeluaran yang rela dikeluarkan untuk membeli produk kosmetik sebesar Rp 300.000,00 - Rp 500.000,00 mendominasi jawaban kuisioner. Setiap kelompok responden memiliki jawaban yang tersebar secara merata.

\section{Analisa Multi Dimensional Scalling (MDS)}

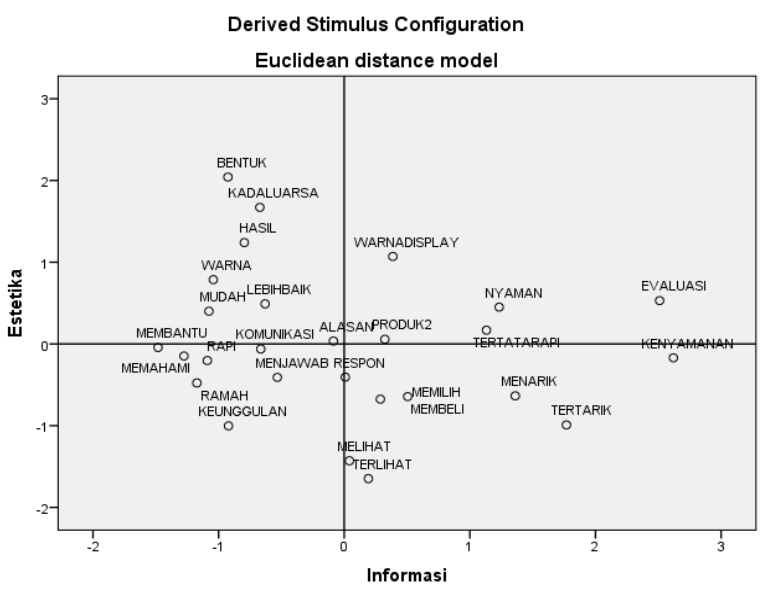

Gambar 2.Multi Dimensional Scalling
Pada kuadran I, responden menilai estetika dan informasi yang di dapat dari LT Pro, terdapat di dalamnya indikator warna display (window display), produk-produk (window display), nyaman (lighting), tertata rapi (product presentation), dan evaluasi (store design). Kenyataannya di lapangan, responden melihat indikator-indikator tersebut secara langsung, dengan produk yang terlihat di dalam window display dan menggunakan perpaduan warna yang menarik juga produk yang telah ditata dengan rapi serta adanya pencahayaan yang nyaman membuat responden dapat melakukan evaluasi secara keseluruhan terhadap counter sehingga indikator-indikator ini memiliki nilai estetika dan informasi yang tersampaikan kepada responden.

Pada kuadran II dimana terdapat nilai estetika namun tidak terjadi pertukaran informasi, terdapat di dalamnya indikator bentuk (aesthetics), warna (aesthetics), kadaluarsa (perceived quality), hasil (perceived quality), lebih baik (perceived quality), mudah (perceived quality), dan alasan (window display). Estetika menjadi dimensi yang paling berpengaruh di dalam window display karena dengan adanya estetika maka responden merasa tertarik dan memilih untuk mengunjungi counter dengan tidak begitu memperhatikan apakah ada informasi yang diterima atau tidak. Product quality dari LT Pro memiliki tampilan dan feature yang bagus sehingga dianggap memiliki nilai estetika yang baik. namun untuk mengetahui informasi sebuah kualitas produk melihat saja tidak cukup, responden harus dapat merasakan, salah satu caranya adalah dengan adanya tester di setiap counter.

Pada kuadran III terdapat indikator kenyamanan (store design), tertarik (lighting), menarik (product presentation), melihat (in-store display), memilih (instore display), membeli (signage), terlihat (signage), dan respon (expertise). Papan promosi yang digunakan LT Pro secara padat dan jelas memberikan informasi yang diperlukan oleh responden, namun sayangnya media yang digunakan belum dianggap indah atau menarik karena papan promosi yang digunakan LT Pro kebanyakan masih menggunakan gambar produk lama atau berbentuk terlalu biasa sehingga tidak memiliki ciri khas yang dapat membedakan dengan merek lain.

Pada kuadran IV terdapat indikator menjawab (expertise), keunggulan (expertise), membantu (likeability), rapi (likeability), ramah (likeability), memahami (customer-oriented), dan komunikasi (customer-oriented). personal selling LT Pro dianggap belum menarik dan tidak ada informasi yang diterima dapat dikarenakan penampilan dari personal selling LT Pro yang terlihat kaku dan kurang 
feminine, contohnya adalah seragam yang digunakan personal selling didominasi oleh warna hitam dan hanya terdapat satu garis berwarna fuchia. Namun, dengan bantuan dari variabel di kuadran I atau kuadran II responden akan berhadapan dengan personal selling sehingga dapat terjadi penyampaian informasi antara personal selling dan responden.

\section{Analisa Cluster}

Tabel 1. Analisa Cluster

\begin{tabular}{lcc}
\hline \multicolumn{3}{l}{ Number of Cases in each Cluster } \\
\hline Cluster & 1 & 22.000 \\
& 2 & 12.000 \\
& 3 & 66.000 \\
\hline Valid & 100.000 \\
\hline Missing & .000 \\
\hline
\end{tabular}

LT Pro terbagi menjadi tiga kelompok responden yang dapat disebut sebagai kelompok 'penggemar, kelompok 'pembenci' dan kelompok 'netral'. LT Pro ternyata memiliki lebih banyak konsumen yang masih bersifat 'netral' dimana konsumen yang memiliki sifat ini tidak sangat menyukai LT Pro namun juga tidak membenci produk LT Pro. Konsumen LT Pro masih merupakan konsumen yang dapat memilih produk atau merek kosmetik lain dan belum menjadikan LT Pro sebagai pilihan utama. Hal ini dapat dikarenakan LT Pro belum di asosiasikan secara penuh oleh perusahaan. Sehingga hal ini merupakan pekerjaan untuk LT Pro bagaimana menarik konsumen yang masih bersifat 'netral' untuk sampai kepada tahap 'penggemar'.

\section{Analisa Regresi Linier Berganda}

\section{Uji Asumsi Klasik}

- Uji Normalitas

Normal P-P Plot of Regression Standardized Residual

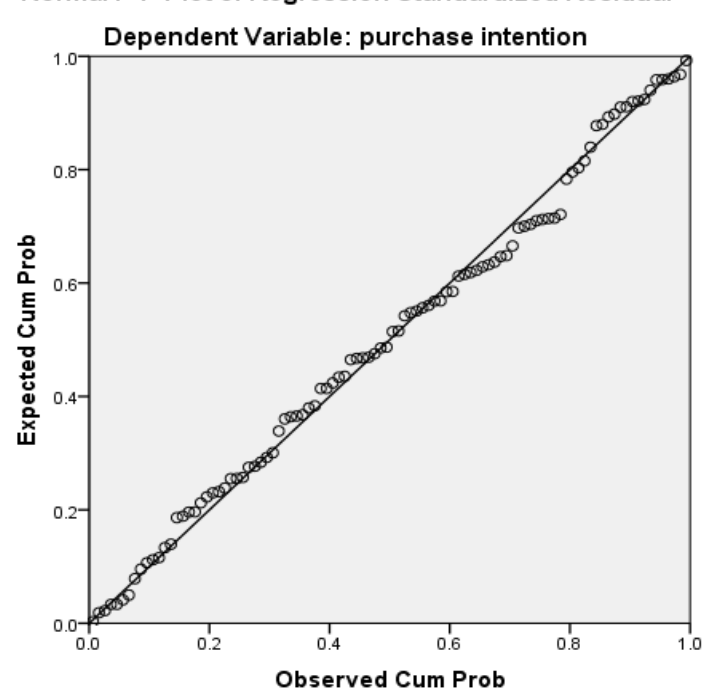

Gambar 3.Uji Normalitas
Dari gambar di atas dapat dilihat bahwa pola distribusi terbentuk normal atau tidak adanya kemencengan (skewness). Sehingga model regresi di dalam penelitian ini memenuhi asumsi normalitas.

- Uji Multikolonieritas

Tabel 2.Uji Multikolonieritas

\begin{tabular}{llrr}
\hline \multirow{2}{*}{ Model } & \multicolumn{2}{c}{ Collinearity Statistics } \\
\cline { 2 - 4 } & Tolerance & VIF \\
\hline 1 & (Constant) & & \\
& visual & .374 & 2.671 \\
& merchandise & .296 & 3.376 \\
& personal selling & .367 & 2.727 \\
\hline
\end{tabular}

Nilai Variance Inflation Factors (VIF) dari setiap variabel dependen tidak ada yang lebih dari angka 10 dan tingkat tolerance setiap varibel dependen lebih dari 0.10 yang berarti menandakan bahwa tidak adanya korelasi antar variabel dependen yang nilainya lebih dari $95 \%$.

2. Uji Korelasi

Tabel 3.Uji Korelasi

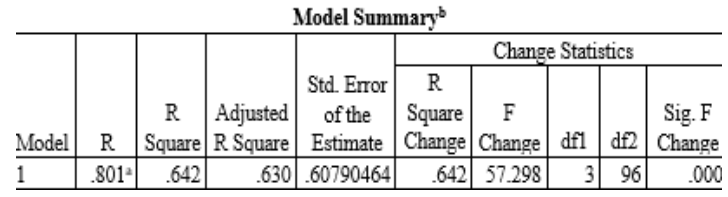

Nilai R sebesar 0.801 yang menunjukkan adanya korelasi atau hubungan kuat antara variabel indepeden dan variabel dependen.Sehinga dapat disimpulkan bahwa pemilihan variabel untuk penelitian ini tepat.

3. Koefisien Determinasi

Nilai dari Adjusted $R$ Squaresebesar 0.630 atau 63\% yang menandakan bahwa $63 \%$ purchase intention dapat dijelaskan oleh visual merchandising, personal selling dan product quality. Sedangkan sisa dari presentase tersebut, yaitu sebesar 37\% dari purchase intention dapat dipengaruhi oleh variabel-variabel lain yang tidak masuk dalam penelitian ini.

4. Uji Statistik F

Tabel 4.Uji F

\begin{tabular}{|c|c|c|c|c|c|c|}
\hline \multicolumn{7}{|c|}{ ANOVA $^{2}$} \\
\hline \multicolumn{2}{|c|}{ Model } & $\begin{array}{l}\text { Sum of } \\
\text { Squares }\end{array}$ & df & $\begin{array}{l}\text { Mean } \\
\text { Square }\end{array}$ & $\mathrm{F}$ & Sig. \\
\hline 1 & Regression & 63.523 & 3 & 21.174 & 57.298 & $.000^{4}$ \\
\hline & Residual & 35.477 & 96 & .370 & & \\
\hline & Total & 99.000 & 99 & & & \\
\hline
\end{tabular}

Nilai $F_{\text {hitung }}$ sebesar 57.298 dengan signifikansi sebesar 0.000 yang mana bernilai lebih kecil dari 
$0.05(0.000<0.05)$ menunjukkan bahwa secara bersama-samaan, variabel visual merchandising, personal selling dan product quality mempunyai pengaruh yang signifikan terhadap purchase intention sehingga kerangka konseptual penelitian ini dinilai layak.

5. Uji Statistik T

Tabel 5. Uji T

\begin{tabular}{c|r|r|r|r|r}
\hline \multirow{2}{*}{ Model } & \multicolumn{2}{|c|}{$\begin{array}{c}\text { Unstandardized } \\
\text { Coefficients }\end{array}$} & $\begin{array}{c}\text { Standardized } \\
\text { Coefficients }\end{array}$ & & \\
\cline { 2 - 4 } & \multicolumn{1}{|c|}{$\mathrm{B}$} & Std. Error & \multicolumn{1}{c|}{ Beta } & \multicolumn{1}{c}{$\mathrm{t}$} & \multicolumn{1}{c}{ Sig. } \\
\hline (Constant) & $1.732 \mathrm{E}-16$ & .061 & & .000 & 1.000 \\
visual merchandise & .058 & .100 & .058 & .576 & .566 \\
personal selling & .348 & .112 & .348 & 3.097 & .003 \\
product quality & .453 & .101 & .453 & 4.486 & .000 \\
\hline
\end{tabular}

Tabel 6. Kesimpulan Uji Hipotesis

\begin{tabular}{c|l|c} 
Hipotesis & \multicolumn{1}{|c|}{ Keterangan } & Sig. \\
\hline $\mathrm{H}_{1}$ & $\begin{array}{l}\text { Tidak terdapat pengaruh signifikan dari Visual } \\
\text { Merchandising terhadap Purchase Intention }\end{array}$ & 0.576 \\
\hline $\mathrm{H}_{2}$ & $\begin{array}{l}\text { Terdapat pengaru signifikan dari Personal } \\
\text { Sellingterhadap Purchase Intention }\end{array}$ & 0.003 \\
\hline $\mathrm{H}_{3}$ & $\begin{array}{l}\text { Terdapat pengaruh signifikan dari Product Quality } \\
\text { terhadap Purchase Intention }\end{array}$ & 0.000
\end{tabular}

\section{Pembahasan}

\section{Visual Merchandising terhadap Purchase Intention}

Visual merchandising tidak memiliki pengaruh yang signifikan terhadap purchase intention. Hal ini dapat dikarenakan store design yang kecil dan kuno juga signage yang menggunakan gambar yang kurang menarik menjadikan visual merchandising LT Pro tidak dapat membentuk minat beli konsumen.

\section{Personal Selling terhadap Purchase Intention}

Personal selling memiliki pengaruh yang signifikan terhadap purchase intention. Hal tersebut dapat dikarenakan beauty advisor dapat mengetahui kebutuhan dari konsumen dan kemudian menyesuaikannya dengan produk yang dimiliki oleh LT Pro untuk menjawab kebutuhan konsumen sehingga akhirnya terbentuklah minat beli di dalam konsumen.

\section{Product Quality terhadap Purchase Intention}

Variabel produt quality LT Pro sendiri memiliki pengaruh yang signifikan terhadap purchase intention konsumen. Konsumen yang sudah mengetahui bagaimana rasa, hasil, bentuk dari produk LT Pro dan menemukan bahwa kualitas dari produk LT Pro ternyata sesuai dengan yang diharapkan, menyebabkan terbentuklah sebuah minat beli di dalam konsumen.

\section{KESIMPULAN DAN SARAN}

\section{Kesimpulan}

Berdasarkan pembahasan di atas, maka dapat disimpulkan:

1. Visual merchandising secara statistik tidak memiliki pengaruh yang signifikan terhadap purchase intention padaproduk kosmetik LT Pro, hal ini dapat dikarenakan beberapa dimensi dari visual merchandising masih memiliki kekurangan di dalam implementasi di lapangan. Namun beberapa dimensi lainya dianggap telah memiliki nilai estetika yang baik bagi konsumen dan dapat memberikan informasi yang diperlukan oleh konsumen.

2. Personal selling secara statistik memiliki pengaruh yang signifikan terhadap purchase intention pada produk kosmetik LT Pro. Meskipun personal selling tidak memiliki nilai estetika bagi konsumen dan tidak dapat memberikan informasi secara langsung namun apabila terjadi kontak antara konsumen dengan personal selling, personal selling LT Pro yang memiliki product knowledge yang kuat dan kompetenti yang baik dapat menjawab kebutuhan konsumen.

3. Product quality secara statistik memiliki pengaruh yang signifikan terhadap purchase intention pada produk kosmetik LT Pro, dikarenakan produk LT Pro memiliki packaging, cara penggunaan dan hasil yang telah disesuaikan dengan kebutuhan pasar.

4. Kelompok konsumen LT Pro terbagi menjadi tiga kelompok, yaitu 'penggemar', 'netral' dan 'pembenci'. Namun LT Pro masih didominasi oleh kelompok konsumen 'netral' sehingga dapat dikatakan bahwa LT Pro masih harus berjuang untuk mempertahankan posisinya di dalam konsumen.

\section{Saran}

1. LT Pro dapat meningkatkan penerapan visual merchandising yang telah digunakan selama ini.

2. LT Pro dapat mempertahankan kinerja personal selling yang sudah ada.

3. LT Pro dapat mempertahankan dan meningkatkan product quality yang sudah dimiliki.

\section{UCAPAN TERIMA KASIH}

Penulis ingin mengucapkan terima kasih kepada semua oihak yang telah membantu menyelsaikan penelitian ini, terutama kepada dosen pembimbing, rekan kerja PT. Rembaka Surabaya, keluarga, dan saudara sekalian. 


\section{DAFTAR PUSTAKA}

Bell, J., \& Ternus, K. (2012). Silent selling: best practices and effective strategies in visual merchandising (4th ed.). canada.

cci-indonesia.com. (2016). Perkembangan Pasar Industri Kosmetik Di Indonesia, 2010 - 2015 Citra Cendekia Indonesia. Retrieved from http://cci-indonesia.com/2016/06/17/perkembangan-pasar-industri-kosmetik-di-indonesia2010-2015/

Chiang, C.-T. (2010). Research of Female Consumer Behavior in Cosmetics Market Case Study of Female Consumers in Hsinchu Area Taiwan. iBusiness, 2(4), 348-353. https://doi.org/10.4236/ ib. 2010.24045

Ebster, C. (2011). Store Design and Visual Merchandising: Creating Store Space That Encourages Buying. (N. Malhotra, Ed.) (First Edit). New York: Business Expert Press. Retrieved from http://books.google.com/books?hl=en\&lr=\&id= $1 \mathrm{~kg} 8$ S3LuzCQC\&pgis $=1$

Ghozali, I. (2013). Aplikasi Analisis Multivariate dengan Program SPSS. Semarang: Universitas Diponegoro.

Ingram, T., La Forge, R., Avila, R., Schwepker Jr., C., \& Williams, M. (2004). Sales Management: Analysis dan Decision Making (Fifth Edit). United States: Thomson South-Western.

Kotler, P., \& Armstrong, G. (2008). Prinsip-Prinsip Pemasaran (Edisi 12). Jakarta: Erlangga.

Levy, M., Weitz, B., \& Grewal, D. (2014). Retailing Management (9th ed.). New York: McGrawHill Education.

lt-pro.com. (2016). Tentang Kami | LT-Pro | La Tulipe Profesional - Make Up. Retrieved from http://lt-pro.com/ID/aboutus/
Malhotra, N.K. (2004). Marketing research: an applied orientation (4th Editio). New Jersey: Upper Saddle River.

Mirabi, V., Akbariyeh, H., \& Tahmasebifard, H. (2015). A Study of Factors Affecting on Customers Purchase Intention Case Study: the Agencies of Bono Brand Tile in Tehran. Journal of Multidisciplinary Engineering Science and Technology (JMEST), 2(1), 267-273. https://doi. org/10.1017/CBO9781107415324.004

Schiffman, L. G., \& Kanuk, L. L. (2000). Consumer Behavior. (5th Edition, Ed.). Prentice-Hall, Inc.

Shaharudin, M.R., Mansor, S.W., Hassan, A.A., Omar, M.W., \& Harun, E.H. (2011). The relationship between product quality and purchase intention: The case of Malaysia's national motorcycle/scooter manufacturer. African Journal of Business Management, 5(20), 8163-8176. https://doi.org/http://dx.doi.org/10.5897/AJBM1 1.267

Simamora, B. (2002). Panduan Riset Perilaku Konsumen. Jakarta.

Sugiyono. (2009). Metode penelitian bisnis: pendekatan kuantitatif, kualitatif, dan $R \& D$ (Cetakan 14). Bandung: Alfabeta.

Sugiyono. (2010). Metode Penelitian Bisnis: Pendekatan Kuantitatif, Kualitatif dan $R \& D$. Bandung: Alfabeta.

Sullivan, M., \& Adcock, D. (2002). Retail Marketing (1st ed.). London: Thomson.

Tee, P.K., Gharleghi, B., Chan, B., Samadi, B., \& Balahmar, A.A. (2015). Purchase Intention of International Branded Clothes Fashion among Younger's in Jakarta. International Journal of Business and Social Research, 5(8), 08-17. 